\title{
THE IDENTIFICATION OF THE FACTORS WITH REGARD TO THE INFLUENCE OF REFERENCE GROUPS ON THE THEATRICAL MARKET IN THE CZECH REPUBLIC
}

\author{
[Identifikácia faktorov vplyvu referenčných skupín na divadelnom trhu v \\ Českej republike]
}

Katarína Seifriedová ${ }^{1}$ ${ }^{1}$ Vysoká škola báňská-Technická univerzita Ostrava, Ekonomická fakulta, Sokolská 33, 70121 Ostrava
Email:katarina.seifriedova@ vsb.cz

\begin{abstract}
The paper focuses on the theatre market in the Czech Republic and examines the influence of reference groups within this market. It specifically focuses on the information influence, the utilitarian influence and the influence expressing value. The aim of the paper is to identify factors that would reflect the influence of reference groups. The correlation analysis and factor analysis were used for this purpose. Respondents who participated in the online survey expressed their agreement with fourteen statements concerning the three influences of the reference groups which were mentioned. They were evaluated using a seven-point Likert scale. The data were collected from 154 respondents who have visited theatre performances at least once in the last 2 years. The collected data were weighted at first as they did not correspond to the relative distribution of the population of the Czech Republic by gender. The data then entered a factor analysis. The result of this analysis was the emergence of four factors influencing the reference groups. They were named as: social influence, influence of relatives, professional influence and media influence. The paper describes the theoretical basis of the influence of reference groups, followed by methodology and analytical procedure. The conclusion contains an evaluation of the fulfilment of goals and possible use of the results.
\end{abstract}

Keywords: correlation analysis, factor analysis, marketing, reference groups, social influence, theatrical market.

JEL classification: C38, M30, M31

Received: 14.6.2020; Reviewed: 24.6.2020; 25.6.2020; 2.7.2020; Accepted: 9.9.2020

\section{Úvod}

$\mathrm{V}$ posledných rokoch sa do popredia v oblasti marketingu dostávajú rôzne osoby, či skupiny osôb, ktoré dokážu svojimi názormi značne ovplyvnit' správanie iných. Hovoríme o nich ako o referenčných skupinách, no stretávame sa aj s pojmami ako opinion leaderi alebo influenceri. Výskum sociálneho a interpersonálneho vplyvu môže byt' počítaný od Hymana (1942), ktorý ako prvý použil termín „referenčná skupina“. Niet pochýb, že každá osoba je obklopená radou osôb či skupín, ktorej názor berie do úvahy pri svojom nákupnom či bežnom rozhodovaní.

Problematika vplyvu referenčných skupín bola skúmaná už v mnohých odvetviach trhu a aplikovaná na rôzne produkty či služby, i ked' služby boli skúmané len minoritne. Burnkrant a Cousineau (1975) skúmali vplyv referenčných skupín na výber kávy, Mehta, Lalwani a Ping (2001) sa zamerali na služby reštaurácie, kaderníka, dentálne služby a starostlivosti o telo, Yang, He a Lee (2007) skúmali mobilné telefóny, Hoffmann a Broekhuizen (2009) sa orientovali na investovanie. Mnohí autori volili vo svojich výskumoch i mix rôznych produktov každodennej potreby. Boli nimi napríklad Park a Lessig (1977), Bearden, Netemeyer a Teel (1989), Childers a Rao (1992) alebo Greco (2014). V oblasti divadelného trhu podobný výskum chýba, preto sa autorka príspevku rozhodla zamerat' práve na výskum vplyvu referenčných skupín v tomto tržnom odvetví. 
Ciel'om tohto príspevku je identifikovat' faktory vplyvu referenčných skupín, ktoré pôsobia na divadelnom trhu v Českej republike. Tento ciel' bude naplnený pomocou využitia faktorovej analýzy, do ktorej bude vstupovat' štrnást' tvrdení, ktoré boli využité v dotazníkovom šetrení. Tieto tvrdenia boli získané rešeršou odbornej literatúry v oblasti vplyvu referenčných skupín. Príspevok je koncipovaný do empirickej a praktickej časti. Empirická čast' definuje referenčné skupiny, jednotlivé vplyvy referenčných skupín a aplikáciu voblasti služieb. Praktická čast' je rozdelená do viacerých kapitol a popisuje metodiku výskumu, analytickú čast' výskumu, ktorá zahŕňa postup identifikácie nových faktorov vplyvu referenčných skupín, výsledky a diskusiu.

\section{Teoretické vymedzenie referenčných skupín a ich vplyvu}

Sociálny vplyv funguje podla Kelmana (1961) prostredníctvom jedného alebo viacerých z troch rôznych procesov. Ide o internalizáciu, identifikáciu a súlad. O internalizácii sa hovorí, ked' jedinec akceptuje sociálny vplyv, pretože ho vníma ako silu, ktorá môže maximalizovat' jeho hodnoty. Hodnoty závisia na tom, aké ciele má jedinec stanovené. Identifikácia nastane, ked' jedine preberá správanie alebo názor niekoho iného, pretože toto správanie identifikuje ako to, ktoré mu prináša uspokojenie. Súlad nastáva v momente, ked' jedinec spíňa očakávanie iného človeka s ciel'om získat' odmenu alebo vyhnút' sa trestu. Každý z týchto procesov je prepojený s jedným typom vplyvu referenčných skupín, ktoré popísal Deutsch a Gerard (Burnkrant a Cousineau 1975) a na nich nadviazali Park a Lessig (1977). Medzi tieto vplyvy radíme informačný vplyv, vplyv vyjadrujúci hodnotu a utilitárny vplyv.

Deutsch a Gerard (1955) uznali, že existujú dva sociálne vplyvy (informačný a normatívny). Informačný vplyv popisovali ako vplyv akceptovania informácií, ktoré boli získané od niekoho iného ako dôkaz o reálnom jave. Informačný vplyv je založený na túžbe spotrebitel'ov robit' informované rozhodnutia. Informačný vplyv funguje iba vtedy, ked' spotrebitel' vníma rady členov referenčných skupín ako potenciálne užitočné a vezme ich do úvahy. Je využívaný najmä vtedy, ked' spotrebitel' nemá znalosti o určitom výrobku (Yang, He a Lee 2007).

Informačný vplyv je popisovaný ako akceptovaný spotrebitel'om vtedy, ked' referenčná skupina zvyšuje svojimi radami vedomosti spotrebitel'a, alebo má schopnost' vysporiadat' sa s nejakou situáciou, usmernit' správanie spotrebitel'a (napr. nákupné správanie) (Kelman 1961). Jednotlivec môže použit' informačné referencie dvoma rozdielnymi spôsobmi. Prvým z nich je aktívne hl'adanie informácií od názorových vodcov alebo celej skupiny, ktorí majú s problémom alebo potrebou skúsenosti. Druhým spôsobom je, ked' jednotlivec urobí nejaký záver nad riešením situácie na základe toho, že sleduje správanie iných (Park a Lessig 1977; Yang, He a Lee 2007).

Vplyv referenčných skupín vyjadrujúci hodnotu možno najlepšie vysvetlit' "procesom identifikácie", v ktorom sú l'udia ochotní lepšie vyjadrit' svoju osobu spoločnosti tým, že sa podobajú skupine, ku ktorej chcú patrit'. Tento vplyv je spojený so snahou jednotlivca zvýšit' alebo podporit' samého seba. Od človeka sa môže očakávat', že bude spolupracovat' s pozitívnymi referentmi, poprípade že sa bude snažit' nedostávat' sa do kontaktu a neprijímat' rady od negatívnych referentov (Kelman 1961).

Tento vplyv zároveň vysvetl'ujú dva procesy. Prvým z nich je, ked' jednotlivec využíva referenčné skupiny, aby vyjadril svoju osobnost', spôsob životného štýlu, alebo si zvýšil ego. Tu je vzt’ah medzi túžbou ukázat' sa a psychologickým obrazom, ktorý sa prikláňa k referenčnej skupine. Druhý proces sa prejavuje, ked' je jednotlivec ovplyvnený 
referenčnými skupinami z toho dôvodu, že s nimi proste sympatizuje. Tu nie je dôležité ani to, že to nie je pre referenčné skupiny relevantné (Park a Lessig 1977; Yang, He a Lee 2007).

Utilitárny vplyv referenčných skupín možno vysvetlit' takzvaným "procesom dodržiavania pravidiel", v ktorom je jednotlivec ochotný uspokojit' očakávania určitých skupín (Yang, He a Lee 2007). Tento vplyv sa v označuje aj ako normatívny a autori ho tiež popisujú ako vplyv, kedy sa jedinec prispôsobuje predstavám iných osôb (Deutsch a Gerard 1955). Znamená to, že sa jednotlivec správa podl'a nejakej normy a snaží sa správat' podl'a tých rád a referenčných skupín ktoré vníma, že mu môžu priniest' nejakú odmenu, alebo sa tak vyhne trestu, ktoré mu umožnia to, že si jeho správanie všimnú iní l’udia alebo ktoré vie, že budú ocenené.

K tomuto vplyvu dochádza len vtedy, ked’ jedinec vie, že jeho správanie je referenčným skupinám známe a je viditel'né (Park a Lessig 1977). Na rozdiel od informačného vplyvu je možné povedat', že utilitárny vplyv a vplyv vyjadrujúci hodnotu sú vplyvy odvodené od stanovených hodnôt a noriem, ktoré sprevádza členstvo v konkrétnych sociálnych skupinách (Park a Lessig 1977).

Pôsobenie spomínaných vplyvov bolo už skúmané v mnohých výskumoch. Výsledky týchto výskumov potvrdzujú, že interpersonálny vplyv je významných determinantom správania l'udí (Mothersbaugh a Hawkins 2015). Ako je spomenuté v úvode, autori sa zaoberali vplyvom referenčných skupín u rôznych produktov či služieb. Niektorí autori podrobili výskumu mix produktov alebo služieb, ktoré mali rozdelené do štyroch skupín (Childers a Rao 1992; Arora a Stoner 1995). Tie boli vytvorené podl'a toho, či ide o luxusné alebo nutné produkty alebo služby a či $\mathrm{k}$ ich spotrebe dochádza verejne alebo privátne. Na základe týchto podmienok vznikli štyri skupiny. Ide o verejne spotrebovávané luxusné statky (návšteva reštaurácie), verejne spotrebovávané nutné statky (služby kaderníka), privátne spotrebovávané luxusné statky (sledovanie káblovej televízie) a privátne spotrebovávané nutné statky (bankové služby).

Z hl'adiska tohto rozdelenia je možné návštevu divadelného predstavenia zaradit' do verejne spotrebovávaných luxusných služieb. Dôvodom je to, že divadelné predstavenia sa odohrávajú pred väčším počtom návštevníkov a zároveň ide o vol'nočasovú aktivitu, ktorá vyžaduje vynaloženie finančných prostriedkov. Návštevou divadla spotrebitelia neuspokojujú základné životné potreby, preto ide o prémiovú (luxusnú) službu.

Arora a Stoner (1995) vo svojom výskume tvrdia, že u verejne spotrebovávaných luxusných služieb je silný vplyv referenčných skupín. Toto potvrdili aj Mehta, Lalwani a Ping (2001), ktorí sa tiež orientovali na výskum vplyvu referenčných skupín na služby. Títo autori prepojili vplyv referenčných skupín s nákupných rizikom. Podl'a nich platí, že čím väčšie nákupné riziko spotrebitelia pocit’ujú, tým väčší vplyv majú na ich rozhodovanie referenčné skupiny.

\section{Metodika výskumu}

V tejto časti je charakterizovaný prístup k metodike, hlavný ciel', využité metódy a to, ako výskum prebiehal. Ciel'om príspevku je teda identifikovat' faktory vplyvu referenčných skupín, ktoré pôsobia na divadelnom trhu v Českej republike. Aby bolo možné skúmat' postoje spotrebitel'ov na divadelnom trhu, bolo uskutočnené dotazníkové šetrenie, ktoré prebiehalo na území Českej republiky. Pre tento účel bolo využité online dotazovanie, ktoré bolo vybrané najmä kvôli rýchlosti vyplnenia a možnosti rýchleho rozposlania v Českej republike. Zároveň mali respondenti viac času porozmýšl'at' nad otázkami. Dotazník 
pozostával z viacerých otázok, no pre účely tohto príspevku je podstatná len postojová otázka a demografická otázka, ktorá sa týkala pohlavia respondentov.

Postojová otázka pozostáva zo štrnástich tvrdení. Jednotlivé tvrdenia sa týkali vplyvov referenčných skupín. Informačného vplyvu sa týkalo šest' tvrdení (T1-T6), utilitárneho vplyvu (T7-T10) a vplyvu vyjadrujúceho hodnotu (T11-T14) sa týkali zhodne štyri tvrdenia. Tvrdenia boli prevzaté z odbornej literatúry, kde ich vo svojich výskumoch využili už mnohí autori, medzi nimi napríklad Park a Lessig (1977), Yang, He a Lee (2007), Fernandes a Londhe (2015). Tieto tvrdenia boli mierne upravené pre účely výskumu na divadelnom trhu. Respondenti mali vyjadrit' mieru svojho súhlasu s týmito tvrdeniami na Likertovej škále od 1 do 7, kde 1 znamenalo úplný súhlas a 7 úplný nesúhlas. Presné znenie tvrdení bolo nasledujúce:

- T1 - Hladám informácie a o divadlách a divadelných predstaveniach od odborníkov (divadelných kritikov).

- T2 - Hladám informácie o divadlách a divadelných predstaveniach od častých návštevníkov divadla.

- T3 - Získavam informácie o divadelných predstaveniach od pracovníkov divadla.

- T4 - Hl'adám informácie o divadlách a divadelných predstaveniach od priatel'ov, známych a rodiny.

- T5 - Ak vidím, že je divadelné predstavenie navštevované známymi osobnost’ami a je oň vel'ký záujem, je pravdepodobné, že ma to presvedčí ku kúpe.

- T6 - Môj výber predstavenia je ovplyvnený informáciami, ktoré sa dopočujem, alebo ktoré sa dozviem vd'aka sociálnym siet'am.

- T7 - Preferencie a hodnotenie mojich priatel'ov ovplyvňujú moje rozhodovanie.

- T8 - Aby som naplnil očakávania kolegov a nadriadených, môj výber predstavenia ovplyvňujú ich preferencie.

- T9 - Odporúčania iných osôb silne ovplyvňujú môj výber divadelného predstavenia.

- T10 - Preferencie mojej rodiny ma ovplyvňujú pri výbere divadelného predstavenia.

- T11 - Vyberám si divadelné predstavenia, ktoré zlepšia môj image v očiach spoločnosti.

- T12 - Cítim, že by som sa chcel podobat' tým, ktorý často navštevujú divadelné predstavenia.

- T13 - Myslím si, že tí, ktorí navštevujú často divadelné predstavenia, sú rešpektovaní spoločnost'ou.

- T14 - Myslím si, že to, že navštevujem divadlo, ukazuje ostatným aký som (aký by som chcel byt').

Pred samotným zahájením dotazovania prebehla pilotáž, ktorej sa celkovo zúčastnilo 5 osôb. Nakol'ko bol dotazník v českom jazyku, prebehla počas pilotáže jazyková korektúra, kde boli napravené gramatické nedostatky a taktiež prebehla kontrola funkčnosti dotazníka v online prostredí a kontrola toho, či sú otázky pre respondentov zrozumitel'né.

\subsection{Základný a výberový súbor}

Základný súbor pozostáva zo všetkých obyvatel'ov Českej republiky s trvalým pobytom, ktorí sa pohybujú na internetových stránkach, kde bol dotazník zverejnený, poprípade, ktorí boli oslovení pomocou osobného vzt'ahu s autorkou príspevku alebo jej rodiny. Výberový súbor navyše musel spĺn̆at' podmienku, že jeho členovia navštívili divadlo za posledné dva roky aspoň jedenkrát. Z celkového počtu 190 odpovedí bolo vd'aka tejto podmienke odstránených 
36 odpovedí. Výberový súbor obsahuje 154 respondentov. Získané dáta boli d’alej spracované do dátovej matice v MS Excel a analyzované v IBM SPSS.

Autorka príspevku mala záujem zistit’ štruktúru návštevníkov divadla v Českej republiky pre zaistenie reprezentatívnosti výberového súboru, no podobná štatistika nie je zatial' $\mathrm{k}$ dispozícii. Z toho dôvodu bol výberový súbor aspoň upravený tak, aby odrážal pomer obyvatel'ov Českej republiky podl'a pohlavia. Na zabezpečenie štruktúry výberového súboru podl'a pohlavia bola použitá metóda kvótneho výberu. K 31.12.2018 žilo v Českej republike 5 405606 žien a 5244194 mužov (CSZO 2019), z čoho plynie, že relatívne zastúpenie žien je v ČR 50,8\% a mužov 49,2\%. Výsledky dotazníkového šetrenia však ukázali, že dotazovania sa zúčastnilo $72,7 \%$ žien a 27,3\% mužov. Na základe toho boli stanovené váhy (Tabul'ka 1) a dáta boli vyvážené v softwari SPSS. V celej analýze sa d’alej pracovalo už s vyváženými dátami.

Tabul'ka 1: Hodnoty váh

\begin{tabular}{|l|l|}
\hline Váhy - Ženy & Váhy - Muži \\
\hline 0,69 & 1,80 \\
\hline
\end{tabular}

Zdroj: Vlastné spracovanie.

\subsection{Metódy analýzy}

Hlavnou metódou, ktorá bola využitá na naplnenie ciel'ov príspevku bola faktorová analýza. Pred prevedením faktorovej analýzy však bola využitá ešte korelačná analýza a to z toho dôvodu, aby sa zistilo, či jednotlivé tvrdenia spolu korelujú.

Korelácia označuje mieru stupňa asociácie dvoch premenných. Hovorí sa, že dve premenné sú korelované, pokial' určité hodnoty jednej premennej majú tendenciu sa vyskytovat' spoločne s určitými hodnotami druhej premennej. Korelačný koeficient nadobúda hodnoty z intervalu $\langle-1 ;+1\rangle$. Pokial' existuje nulová hodnota korelácie, značí to lineárnu závislost' sledovaných dvojíc (Hendl 2004; Pecáková 2008).

Na korelačnú analýzu nadväzovala faktorová analýza. Jedným zo základných cielov faktorovej analýzy je posúdit' štruktúru vzt'ahov sledovaných premenných a zistit' tak, či dovol'uje ich rozdelenie do skupín, v ktorých by študované premenné z rovnakých skupín spolu viac korelovali než premenné z rôznych skupín. Hlavnou úlohou faktorovej analýzy je vytvorit' nové nekorelované premenné - faktory, v nádeji, že umožnia lepšie pochopit' analyzované dáta a prípadne aj iné využitie (Hebák et al. 2007).

Odhad modelu faktorovej analýzy vychádza z metódy hlavných komponentov (1). Základným prístupom je zníženie rozmeru úlohy a vytvárajú sa nové (pomocné) premenné. Pokial' sú premenné $\mathrm{Xj}(\mathrm{j}=1,2, \ldots, \mathrm{m})$ normované (ich stredná hodnota je nula a smerodajná odchýlka jedna), môžeme ich zapísat' ako:

$$
X_{j=} \sum_{l=1}^{L} \lambda_{j l} F_{l}+\varepsilon_{j}
$$

kde $\mathrm{Xj}$ sú premenné, ktoré chceme vyjadrit', j vyjadruje poradie premennej, $\mathrm{F}_{1}$ vyjadruje L spoločných faktorov, ktoré vyvolávajú korelácie medzi premennými, ej sú špecifické (chybové) faktory, ktoré prispievajú k rozptylu jednotlivých pozorovaných premenných, $\lambda \mathrm{j} 1$ sú váhy, ktoré sa nazývajú aj faktorové zát’aže (Hebák et al. 2007; Řezánková, Húšek a Snášel 2009). 
$\mathrm{Na}$ začiatku faktorovej analýzy sa využívajú dva testy, ktorých účelom je zistit' vhodnost' použitia faktorovej analýzy. Je to Keiser-Meyer-Olkinov test adekvátnosti a Bartlettov test sphéricity (Malhotra 2010).

\section{Výsledky analýzy}

Pred samotnou tvorbou faktorov pomocou faktorovej analýzy došlo ešte k overeniu korelácie jednotlivých tvrdení pomocou korelačnej analýzy. Tá ukázala, že vstupné premenné spolu korelujú a do faktorovej analýzy môžu vstúpit' všetky premenné. Vzhl'adom na to, že sa pracuje so škálovou premennou, ktorá má sedem bodov, bol v korelačnej analýze využitý Spearmanov korelačný koeficient. Jednotlivé hodnoty korelácie je možné vidiet' v tabul'ke 2.

Ako je možné v tabul'ke vidiet', najsilnejšiu koreláciu pozitívneho smeru majú tvrdenia T13 a T14 (sila korelácie je 0,770). Znamená to teda, že návšteva divadla vzbudzuje v spoločnosti rešpekt a že jeho návštevníci považujú návštevu divadla za možnost' ako okoliu ukázat', kto sú. Možno to teda chápat' tak, že návštevou divadla u nich dochádza k vyjadreniu samých seba a k snahe dosiahnut' rešpekt.

Najsilnejšiu koreláciu negatívneho smeru majú medzi sebou tvrdenia T4 a T12 (sila korelácie je -0,201). Tieto tvrdenia hovoria o tom, že respondent získava informácie od priatel'ov, rodiny a známych a že by sa chcel podobat' tým, ktorí navštevujú divadelné predstavenia.

Tabul'ka 2: Korelačná matica

\begin{tabular}{|l|l|l|l|l|l|l|l|l|l|l|l|l|l|l|}
\hline & $\mathrm{T} 1$ & $\mathrm{~T} 2$ & $\mathrm{~T} 3$ & $\mathrm{~T} 4$ & $\mathrm{~T} 5$ & $\mathrm{~T} 6$ & $\mathrm{~T} 7$ & $\mathrm{~T} 8$ & $\mathrm{~T} 9$ & $\mathrm{~T} 10$ & $\mathrm{~T} 11$ & $\mathrm{~T} 12$ & $\mathrm{~T} 13$ & $\mathrm{~T} 14$ \\
\hline T1 & & 0,401 & 0,342 & 0,051 & 0,101 &,- 049 &,- 112 & 0,359 &,- 038 &,- 009 & 0,215 & 0,129 & 0,171 & 0,116 \\
\hline T2 & 0,401 & & 0,296 & 0,422 & 0,204 & 0,257 & 0,322 & 0,235 & 0,201 & 0,292 & 0,054 & 0,098 & 0,101 &,- 032 \\
\hline T3 & 0,342 & 0,296 & & 0,024 & 0,015 &,- 088 &,- 004 & 0,310 &,- 045 &,- 015 & 0,191 & 0,227 & 0,228 & 0,234 \\
\hline T4 & 0,051 & 0,422 & 0,024 & & 0,215 & 0,355 & 0,396 & 0,032 & 0,373 & 0,279 &,- 147 &,- 201 &,- 129 &,- 152 \\
\hline T5 & 0,101 & 0,204 & 0,015 & 0,215 & & 0,281 & 0,338 & 0,243 & 0,208 & 0,345 & 0,154 & 0,136 & 0,036 &,- 003 \\
\hline T6 &,- 049 & 0,257 &,- 088 & 0,355 & 0,281 & & 0,512 & 0,032 & 0,272 & 0,442 & 0,053 & 0,026 &,- 104 &,- 163 \\
\hline T7 &,- 112 & 0,322 &,- 004 & 0,396 & 0,338 & 0,512 & & 0,143 & 0,504 & 0,572 & 0,059 & 0,061 & 0,007 &,- 004 \\
\hline T8 & 0,359 & 0,235 & 0,310 & 0,032 & 0,243 & 0,032 & 0,143 & & 0,155 & 0,182 & 0,494 & 0,320 & 0,258 & 0,261 \\
\hline T9 &,- 038 & 0,201 &,- 045 & 0,373 & 0,208 & 0,272 & 0,504 & 0,155 & & 0,483 & 0,092 & 0,074 & 0,108 & 0,084 \\
\hline T10 &,- 009 & 0,292 &,- 015 & 0,279 & 0,345 & 0,442 & 0,572 & 0,182 & 0,483 & & 0,084 & 0,066 &,- 008 & 0,049 \\
\hline T11 & 0,215 & 0,054 & 0,191 &,- 147 & 0,154 & 0,053 & 0,059 & 0,494 & 0,092 & 0,084 & & 0,655 & 0,511 & 0,438 \\
\hline T12 & 0,129 & 0,098 & 0,227 &,- 201 & 0,136 & 0,026 & 0,061 & 0,320 & 0,074 & 0,066 & 0,655 & & 0,662 & 0,660 \\
\hline T13 & 0,171 & 0,101 & 0,228 & $-0,129$ & 0,036 & $-0,104$ & 0,007 & 0,258 & 0,108 & $-0,008$ & 0,511 & 0,662 & & 0,770 \\
\hline T14 & 0,116 &,- 032 & 0,234 & $-0,152$ & $-0,003$ & $-0,163$ & $-0,004$ & 0,261 & 0,084 & 0,049 & 0,438 & 0,660 & 0,770 & \\
\hline
\end{tabular}

Zdroj: Vlastné spracovanie.

Na základe výsledkov korelačnej analýzy bolo možné pristúpit' k redukcii faktorov za pomoci faktorovej analýzy. Bola aplikovaná metóda hlavných komponentov, ktorá sa používa vtedy, ked' chceme minimalizovat' faktory na čo najmenší počet s vysokou mierou rozptylu. Pred samotnou redukciou faktorov sa použil Bartlettov test sphéricity a Kaiser-Mayer-Olkinov test adekvátnosti použitia faktorovej analýzy. Tieto testy pomáhajú určit' vhodnost' použitia faktorovej analýzy. Výsledky testov sú znázornené v tabul'ke 3. 
Bartlettov test sphéricity formuluje nulovú hypotézu ako neexistenciu korelácie medzi testovanými premennými. Signifikancia tohto testu je menšia ako 0,05 , preto je možné nulovú hypotézu zamietnut'. Medzi sledovanými premennými existuje korelácia.

Tabul'ka 3: Výsledky KMO a Bartlettovho testu Sphéricity

\begin{tabular}{|l|ll|}
\hline \multicolumn{2}{|l|}{ KMO and Bartlett's Test } & \multicolumn{2}{|l|}{} \\
\hline Kaiser-Meyer-Olkin Measure of Sampling Adequacy. & Approx. Chi-Square & 846,031 \\
\cline { 2 - 3 } Bartlett's Test of Sphericity & Df & 91 \\
\cline { 2 - 3 } & Sig. & $\mathbf{0 0 0}$ \\
\hline
\end{tabular}

Zdroj: Vlastné spracovanie.

Druhým použitým testom bol Kaiser-Mayer-Olkinov test adekvátnosti. Jeho hodnota sa pohybuje $v$ intervale $\langle 0,1\rangle$ a jeho hodnota by nemala byt' menšia ako 0,5 . Za vhodné sa považuje, ked' je jeho hodnota nad 0,7 . Ako je možné vidiet' $v$ tabul'ke 3 , hodnota tohto testu je 0,731 a je teda vhodné pracovat's faktorovou analýzou.

V d'alšom kroku faktorovej analýzy došlo k redukcii faktorov a k rozhodnutiu o počte novo vzniknutých faktorov. Toto popisuje tabul'ka 4. Bolo použité Kaiserové pravidlo, ktoré hovorí, že o počte faktorov rozhoduje počet hodnôt Eigenvalue väčších ako jedna. V tomto prípade teda $\mathrm{z}$ pôvodných štrnástich premenných vznikli štyri redukované faktory, ktoré vysvetl'ujú 66,47 \% pôvodnej variability.

Tabul'ka 4: Tabul'ka vysvetl'ovaného rozptylu

\begin{tabular}{|c|c|c|c|c|c|c|c|c|c|}
\hline \multicolumn{10}{|c|}{ Total Variance Explained } \\
\hline \multirow[t]{2}{*}{ Component } & \multicolumn{3}{|c|}{ Initial Eigenvalues } & \multicolumn{3}{|c|}{$\begin{array}{l}\text { Extraction Sums of Squared } \\
\text { Loadings }\end{array}$} & \multicolumn{3}{|c|}{$\begin{array}{l}\text { Rotation Sums of Squared } \\
\text { Loadings }\end{array}$} \\
\hline & Total & $\begin{array}{l}\% \text { of } \\
\text { Variance }\end{array}$ & $\begin{array}{l}\text { Cumulative } \\
\%\end{array}$ & Total & $\begin{array}{l}\% \text { of } \\
\text { Variance }\end{array}$ & $\begin{array}{l}\text { Cumulative } \\
\%\end{array}$ & Total & $\begin{array}{l}\% \text { of } \\
\text { Variance }\end{array}$ & $\begin{array}{l}\text { Cumulative } \\
\%\end{array}$ \\
\hline 1 & 3,562 & 25,442 & 25,442 & 3,562 & 25,442 & 25,442 & 2,996 & 21,399 & 21,399 \\
\hline 2 & 3,117 & 22,267 & 47,709 & 3,117 & 22,267 & 47,709 & 2,411 & 17,224 & 38,622 \\
\hline 3 & 1,539 & 10,993 & 58,702 & 1,539 & 10,993 & 58,702 & 2,054 & 14,669 & 53,292 \\
\hline 4 & 1,088 & 7,768 & 66,470 & 1,088 & 7,768 & 66,470 & 1,845 & 13,179 & 66,470 \\
\hline 5 & ,816 & 5,830 & 72,301 & & & & & & \\
\hline 6 & ,693 & 4,947 & 77,248 & & & & & & \\
\hline 7 & 675 & 4,819 & 82,067 & & & & & & \\
\hline 8 & ,561 & 4,010 & 86,077 & & & & & & \\
\hline 9 & ,451 & 3,222 & 89,299 & & & & & & \\
\hline 10 & ,403 & 2,877 & 92,177 & & & & & & \\
\hline 11 & ,382 & 2,731 & 94,908 & & & & & & \\
\hline 12 & ,323 & 2,305 & 97,213 & & & & & & \\
\hline 13 & ,239 & 1,707 & 98,920 & & & & & & \\
\hline 14 & ,151 & 1,080 & 100,000 & & & & & & \\
\hline
\end{tabular}

Zdroj: Vlastné spracovanie.

Za použitia typu rotácie Varimax bolo nájdené riešenie pre redukciu premenných a rozdelenie pôvodných premenných do nových faktorov. Rotovaná matica komponentov, ktorá je v tabul'ke 5, ukazuje rozdelenie štrnástich vstupných premenných do nových redukovaných faktorov. Jednotlivé hodnoty ukazujú, ako premenné korelujú s novým faktorom. V nových faktoroch by mali byt' len premenné, ktorých korelácia je väčšia ako 0,3 . Z toho dôvodu boli z tabul'ky odstránené hodnoty pod touto hodnotou. 
Tabul'ka 5: Rotovaná matica komponentov

\begin{tabular}{|c|c|c|c|c|}
\hline \multicolumn{5}{|l|}{ Rotated Component Matrix } \\
\hline & \multicolumn{4}{|c|}{ Component } \\
\hline & 1 & 2 & 3 & 4 \\
\hline $\begin{array}{l}\text { T14 - Myslím si, že to, že navštevujem divadlo, ukazuje ostatným aký som (aký by } \\
\text { som chcel byt'). }\end{array}$ & ,892 & & & \\
\hline $\begin{array}{l}\text { T13 - Myslím si, že tí, ktorí navštevujú často divadelné predstavenia, sú rešpektovaní } \\
\text { spoločnostou. }\end{array}$ & ,891 & & & \\
\hline $\begin{array}{l}\text { T12 - Cítim, že by som sa chcel podobat' tým, ktorý často navštevujú divadelné } \\
\text { predstavenia. }\end{array}$ &, 818 & & & \\
\hline $\begin{array}{l}\text { T11 - Vyberám si divadelné predstavenia, ktoré zlepšia môj image v očiach } \\
\text { spoločnosti. }\end{array}$ & ,657 & & & ,413 \\
\hline $\begin{array}{l}\text { T4 - Hladám informácie o divadlách a divadelných predstaveniach od priatel’ov, } \\
\text { známych a rodiny. }\end{array}$ & & ,755 & & \\
\hline T7 - Preferencie a hodnotenie mojich priatel'ov ovplyvňujú moje rozhodovanie. & & ,743 & & ,362 \\
\hline T10 - Preferencie mojej rodiny ma ovplyvňujú pri výbere divadelného predstavenia. & & ,737 & & \\
\hline $\begin{array}{l}\text { T1 - Hl'adám informácie a o divadlách a divadelných predstaveniach od odborníkov } \\
\text { (divadelných kritikov). }\end{array}$ & & & ,808 & \\
\hline T3 - Získavam informácie o divadelných predstaveniach od pracovníkov divadla. & & & ,698 & \\
\hline $\begin{array}{l}\text { T2 - Hladám informácie o divadlách a divadelných predstaveniach od častých } \\
\text { návštevníkov divadla. }\end{array}$ & & ,446 & ,673 & \\
\hline $\begin{array}{l}\text { T8 - Aby som naplnil očakávania kolegov a nadriadených, môj výber predstavenia } \\
\text { ovplyvňujú ich preferencie. }\end{array}$ &, 328 & & ,560 & ,374 \\
\hline $\begin{array}{l}\text { T5 - Ak vidím, že je divadelné predstavenie navštevované známymi osobnost’ami a je } \\
\text { oň vel'ký záujem, je pravdepodobné, že ma to presvedčí ku kúpe. }\end{array}$ & & & & ,720 \\
\hline T9 - Odporúčania iných osôb silne ovplyvňujú môj výber divadelného predstavenia. & & ,486 & & ,606 \\
\hline $\begin{array}{l}\text { T6 - Môj výber predstavenia je ovplyvnený informáciami, ktoré sa dopočujem, alebo } \\
\text { ktoré sa dozviem vd’aka sociálnym siet’am. }\end{array}$ & & ,427 & & ,606 \\
\hline
\end{tabular}

Zdroj: Vlastné spracovanie.

Prvý redukovaný faktor je tvorený celkom štyrmi tvrdeniami (T11, T12, T13 a T14). Obsahovo spolu tvrdenia značne súvisia a zapadajú do seba. Týkajú sa vnímania návštevy divadla ako nástroja na zlepšenie vnímania v spoločnosti. Tvrdenia zároveň vyjadrujú, že osoby vnímajú návštevu divadla ako prestížnu akciu a myslia si, že návštevou divadla môžu vzbudit' rešpekt u iných osôb. Faktor je pomenovaný ako sociálny vplyv.

Druhý redukovaný faktor tvoria tri tvrdenia (T4, T7 a T10). Tie sa týkajú úzko najbližšieho okruhu l'udí, ktoré ovplyvňujú človeka. Najčastejšie je to rodina, priatelia a známi. U týchto osôb zároveň aj hl'adajú informácie o divadelných predstaveniach. Tvrdenia naznačujú, že preferencie blízkych referenčných skupín sú pre človeka vel'mi dôležité, preto sa faktor nazýva vplyv blízkych.

Tretí redukovaný faktor zahíňa štyri tvrdenia (T1, T2, T3 a T8). Obsah týchto tvrdení hovorí, že tento faktor zahíňa preferencie a informácie od odborníkov na divadelnom trhu, kolegov, pracovníkov divadla a od l'udí, ktorý divadlo časti navštevujú, preto sa tento faktor nazýva profesný vplyv. Pravdepodobne ide o referenčné skupiny, s ktorými spotrebitel' nemá až taký blízky vzt'ah ako s rodinou a priatel'mi.

Posledný štvrtý redukovaný faktor sa skladá z troch tvrdení (T5, T6 a T9). Tie naznačujú, že človeka môžu ovplyvňovat' aj osoby s ktorými nemá priamy a osobný kontakt, ako napríklad 
celebrity, či osoby na sociálnych siet’ach. Novovzniknutý faktor sa preto nazýva mediálny vplyv.

\section{Diskusia}

Výsledky analýzy ukázali, že na divadelnom trhu v Českej republike je možné vzhl'adom na vplyv referenčných skupín identifikovat’ štyri vplyvy. Ide o vplyv sociálny, vplyv blízkych, profesný vplyv a expertný vplyv. Tieto vplyvy boli pomenované podl'a jednotlivých tvrdení, ktoré sú v konkrétnych vplyvoch zahrnuté. Identifikácia týchto vplyvov ukazuje, že je dôležitý typ referenčných skupín, ktorý daný vplyv vysiela. Toto deklaruje aj odborná literatúra, ktorá sa zaoberá rôznymi typmi referenčných skupín. Napríklad viacerí autori, ktorí porovnávali vplyv osobných a verejných referenčných skupín hovoria o silnejšom vplyve osobných referenčných skupín, s ktorými sa spotrebitelia stretávajú často a osobne (Arora a Stoner 1995; Serralvo, Sastre a João 2010; Greco 2014).

Doposial' odborná literatúra pracovala s tromi vplyvmi referenčných skupín, ktorými bol vplyv informačný, utilitárny a vplyv vyjadrujúci hodnotu. Pri porovnaní týchto vplyvov s vplyvmi, ktoré boli identifikované na divadelnom trhu je možné vidiet' rozdiel v poňatí vplyvov. Toto tradičné rozdelenie vplyvov vysvetl'uje, prečo vplyv referenčných skupín na spotrebitel'ov pôsobí. Dôvodom je teda to, že potrebujú robit' informované rozhodnutia, chcú sa identifikovat' s referenčnou skupinou, sktorou sympatizujú alebo sa chcú udržat' v spoločenskej triede, či v hodnotovom rebríčku iných osôb.

Niet pochýb o tom, že referenčné skupiny a ich rady alebo názory môžu spotrebitel'om pomôct' s prekonaním pocitu nákupného rizika. Zvlášt' u kultúrnych akcií hovorí napríklad Kay, Polonsky a Wong (2012) o tom, že návšteva divadla je spojená aj s neistotou a rizikom. Problémom sú napríklad nároky na čas, finančné prostriedky, prekonanie dojazdovej vzdialenosti a premenlivost' predstavení, ktoré čiastočne odrádzajú l'udí k návšteve tohto typu kultúrnej akcie.

Preto by bolo vhodné v budúcnosti pracovat' s vplyvom referenčných skupín v marketingu tak, aby sa táto neistota spotrebitel'ov dala minimalizovat' a aby sa podarilo divadlám dosiahnut' stanovené ciele, akými je napríklad zvyšovanie povedomia, návštevnosti alebo budovanie značky. Doposial' sa v odborných publikáciách objavili identifikované štyri vplyvy len separovane alebo $\mathrm{v}$ náznakoch, ked’že autori skúmali vplyv informačný, utilitárny a vyjadrujúci hodnotu.

Autorka príspevku sa však domnieva, že príležitost'ou by bolo využit' na divadelnom trhu vplyv blízkych, ktorý patrí medzi často diskutované témy i ked'v iných odvetviach. Tu autori dospeli k niektorým zaujímavým zisteniam. Napríklad výskum, ktorý uskutočnil Arora a Stoner (1995) potvrdil, že členovia menej početných rodín sú viac ovplyvnení rovesníkmi. Osoby z rodín, ktoré majú viac členov sú zase náchylnejší k tomu, byt' ovplyvnení vlastnou rodinou (Kucukali, Ada a Ustun 2009). Fernandes a Londhe (2015) vo svojej pilotnej štúdii zameranej na ženy zistili, že rodina a najmä partneri majú vel'ký vplyv na nákupné rozhodovanie žien. Zároveň však často platí, že pokial' ide o nákup drahých produktov a služieb, partneri sa rozhodujú spoločne (Opić a Đuranović 2014).

Významnú úlohu v dnešnej spoločnosti zohráva aj vplyv médií a sociálnych sietí. Vd’aka svojím povzbudzujúcim a ovplyvňujúcim schopnostiam môžu známe osoby zmenit' niektoré postoje iných členov spoločnosti a byt' vel'mi presvedčiví (Lu, Yao a Yu 2005; Pietro a Pantano 2012). Akékol'vek celebrity ako napríklad herci, modelky alebo iné osobnosti môžu 
byt' vytúženou referenciou a pôsobit' vel'mi presvedčivo ako obchodníci (Kotler, Wong, Saunders a Armstrong 2007).

Prínosom príspevku je uskutočnenie výskumu na divadelnom trhu, ktorí bol doteraz vzhl'adom na vplyv referenčných skupín v pozadí. Autorka príspevku zároveň v časti o teoretických východiskách témy deklaruje, že v oblastí služieb a to hlavne tých verejne spotrebovávaných a luxusných, má téma výskumný potenciál. Vhodné by bolo na výsledky príspevku nadviazat' skúmaním vplyvu konkrétnych typov referenčných skupín.

Príspevok má aj isté limitácie, ktorými je napríklad vel'kost' výberového súboru a jeho štruktúra. V tejto oblasti by bolo vhodné $\mathrm{v}$ budúcnosti pracovat' $\mathrm{s}$ väčším počtom respondentov a zaistit', aby štruktúra výberového súboru odpovedala štruktúre návštevníkov na divadelnom trhu. Pokial' by nebolo možné túto štruktúru divadelného trhu aj nad'alej zistit', je vhodné zlepšit štruktúru výberového súboru aspoň pomocou zapojenia d'alšej kvóty okrem pohlavia. Vhodné by bolo napríklad pridat' ako d'alšiu kvótu vek respondentov, aby sa tak výberový súbor viac priblížil rozloženiu obyvatel'ov Českej republiky.

\section{Záver}

Ciel'om príspevku bolo identifikovat' faktory vplyvu referenčných skupín na divadelnom trhu. Autorka príspevku uskutočnila dotazníkové šetrenie v Českej republike, ktoré prebehlo online formou. Výberový súbor pozostával celkovo zo 154 osôb. Ked’že zastúpenie respondentov vo výberovom súbore malo značnú prevahu žien, došlo k vyváženiu výberového súboru podl'a kvóty, ktorou bolo pohlavie osôb v Českej republike. Do faktorovej analýzy vstupovali tvrdenia, ktoré boli rozdelené na tri skupiny podl'a typu vplyvu referenčných skupín. Išlo o informačný vplyv, utilitárny vplyv a vplyv vyjadrujúci hodnotu. Tieto vplyvy sú definované na základe toho, pod akým zámerom osoby využívajú rady a názory referenčných skupín. Ciel' príspevku bol naplnený, ked’že štrnást' formulovaných tvrdení bolo na základe faktorovej analýzy redukovaných na 4 faktory, ktoré dostali pomenovanie sociálny vplyv, vplyv blízkych, profesný vplyv a mediálny vplyv. Tým, že boli vo faktorovej analýze identifikované až štyri faktory vplyvu referenčných skupín, je možné konštatovat', že pôvodné rozdelenie vplyvov, ktoré definovala odborná literatúra bolo tak transformované na iné, ktoré je možné charakterizovat' podl'a zdroja, odkial' vplyv referenčných skupín pochádza.

Na zistené faktory chce autorka nadviazat' d'alšími výskumami, ktoré budú skúmat' pôsobenie týchto faktorov referenčných skupín v konkrétnych divadlách a budú sa orientovat' aj na vplyv konkrétnych typov referenčných skupín, akými sú napríklad partneri, rodina či známe osobnosti. Takto bude možné zistit', ktorý z vplyvov je vhodné využit' v marketingovej komunikácii divadiel a aké referenčné skupiny je najvhodnejšie použit'. S vybranými vplyvmi sa dá pracovat' a navrhnút' konkrétne komunikačné nástroje. Napríklad pre dominantný vplyv blízkych by bolo vhodné zapojit' nástroje, ktoré cielia na oslovenie konkrétnych typov referenčných skupín, akými sú partneri, priatelia, rodičia a podobne. Vhodné je zapojenie nástrojov digitálneho marketingu, ktoré sú jedným zo súčasných marketingových trendov a ponúkajú možnosti na presné zacielenie osôb, ktoré by divadlá chceli oslovit'. 


\section{Literatúra}

[1] ARORA, R. and Ch. STONER, 1995. Reference Group Influence on Selection of Services. Journal of Customer Service in Marketing \& Management, 1(3), 79-93. ISSN 1533-2675.

[2] BEARDEN, O. W., R. G. NETEMEYER and J. E. TEEL, 1989. Measurement of consumer susceptibility to interpersonal influence. Journal of Consumer Research, 15(4), 473-481. ISSN 0093-5301.

[3] BURNKRANT, R. and A. COUSINEAU, 1975. Informational and normative social influence in buyer behavior. Journal of Consumer Research, 2(3), 206-215. ISSN 00935301.

[4] CHILDERS, T. L. and A. RAO, 1992. The Influence of Familial and Peer-Based Reference Groups on Consumer Decisions. Journal of Consumer Research, 19(2), 198211. ISSN 0093-5301.

[5] ČESKÝ STATISTICKÝ ÚŘAD, 2020. Zaostřeno na ženy a muže - 2019 [online]. 31. december 2019 [vid. 15. januára 2020]. Dostupné z: https://www.czso.cz/csu/czso/zaostreno-na-zeny-a-muze-ffhk87f13g.

[6] DEUTSCH, M. and H. B. GERARD, 1955. A study of normative and informational social influences upon individual judgment. The Journal of Abnormal and Social Psychology, 51(3), 629-636. ISSN 0021-843X.

[7] FERNANDES, S. and B. R. LONDHE, 2015. Influence of social reference group on buying behavior, a comparative study of working and non-working women in Bangalore: A pilot study analysis. Indian Journal of Science and Technology, 8(S6), 95-124. ISSN 0974-6846.

[8] GRECO, A. J., 2014. Differences in susceptibility to reference group influence on brand decisions: Middle aged and elderly group participants. In N. K. MALHOTRA, Proceedings of the 1986 Academy of Marketing Science (AMS) Annual Conference. 4650. ISBN 978-3-319-11100-1.

[9] HEBÁK, P. et al., 2007. Vicerozměrné statistické metody (3). 2. vyd. Praha: Informatorium, ISBN 978-80-7333-001-9.

[10] HENDL, J., 2009. Přehled statistických metod zpracování dat. 3. vyd. Praha: Portál, ISBN 978-80-7367-482-3.

[11] HOFFMANN, O. A. and T. L. J. BROEKHUIZEN, 2009. Susceptibility to and impact of interpersonal influence in an investment context. Journal of the Academy of Marketing Science, 37(4), 488-503. ISSN 1552-7824.

[12] HYMAN, H. H., 1942. The psychology of status. Archives of Psychology, ISBN 0405129742.

[13] KAY, P., M. POLONSKY and E. WONG, 2008. Understanding Barriers to Attendance and Non-Attendance at Arts and Cultural Institutions: A Conceptual Framework. In: ANZMAC 2008 : Australian and New Zealand Marketing Academy Conference: Marketing: Shifting the Focus from Mainstream to Offbeat, 1-7. ISBN 9781863081443.

[14] KELMAN, C. H., 1961. Procceses of Opinion Change. Public Opinion Quarterly, 25(1), 57-78. ISSN 0033-362X.

[15] KOTLER, P., V. WONG, J. SAUNDERS a G. ARMSTRONG, 2007. Moderní marketing. Praha: Grada Publishing, ISBN 978-80-247-1545-2. 
[16] KUCUKALI, R., S. ADA and A. USTUN, 2009. An investigation into the evaluation of spare time activities of students at home and in the school. Procedia-Social and Behavioral Sciences, 1(1), 2562-2567. ISSN 1877-0428.

[17] LU, J., J. E. YAO and C.-S. YU, 2005. Personal Innovativeness, Social Influences and Adoption of Wireless Internet Services via Mobile Technology. The Journal of Strategic Information Systems, 14(3), 245-268. ISSN 0963-8687.

[18] MALHOTRA, N. K., 2010. Marketing Research. An Applied Orientation. Global Edition. 6th ed. New Jersey: Prentice Hall, ISBN 0-13-609423-6.

[19] MEHTA, S. C., A. K. LALWANI and L. PING, 2001. Reference group influence and perceived risk in services among working women in Singapore. Journal of International Consumer Marketing, 14(1), 43-65. ISSN: 0896-1530.

[20] MOTHERSBAUGH, D. L. and D. I. HAWKINS, 2015. Consumer Behavior: Building Marketing Strategy. 13th ed. USA: McGraw-Hill Education. ISBN-13: 978-1259232541.

[21] OPIĆ, S. and M. ĐURANOVIĆ, 2014. Leisure Time of Young Due to Some Sociodemographic Characteristics. Procedia-Social and Behavioral Sciences, 159, 546-551. ISSN 1877-0428.

[22] PARK, C. W. and P. V. LESSIG, 1977. Students and Housewives: Differences in Susceptibility to Reference Group Influence. Journal of Consumer Research, 4(2), 102110. ISSN 0093-5301.

[23] PECÁKOVÁ, I., 2008. Statistika v terénních průzkumech. Praha: Professional Publishing, ISBN 9788074310393.

[24] PIETRO, D. L. and E. PANTANO, 2012. An empirical investigation of social network influence on consumer purchasing decision: the case of Facebook. Journal of Direct, Data and Digital Marketing Practice. 14(1), 18-29. ISSN 1463-5178.

[25] ŘEZÁNKOVÁ, H., D. HÚSEK a V. SNÁŠEL, 2009. Shluková analýza dat (druhé rozšírené vydání). Praha: Professional Publishing, ISBN 978-80-86946-81-8.

[26] SERRALVO, F. A., P. N. SASTRE and B. N. JOÃO, 2010. Reference group influence on consumer decision making process: A study in the Brazilian sports utilitarian vehicles segment. Journal of Academy of Business Economics, 10(2), 157-61. ISSN 1542-8710.

[27] YANG, J., X. HE and H. LEE, 2007. Social reference group influence on mobile phone purchasing behaviour: a cross-nation comparative study. International Journal of Mobile Communications, 5(3), 319-338. ISSN 1470-949X. 